\title{
Evaluation of the methodologies used in clinical trials and effectiveness of chemo-mechanical caries removal with Carisolv ${ }^{\mathrm{TM}}$
}

\section{Avaliação das metodologias utilizadas nos ensaios clínicos e efetividade da remoção químico-mecânica de tecido cariado com Carisolv ${ }^{\circledR}$}

\author{
Marcela Marquezan* \\ Italo Medeiros Faraco Junior** \\ Carlos Alberto Feldens ${ }^{* * *}$ \\ Maximiano Ferreira Tovo** \\ Andréia Bertani Ottoni ${ }^{* * *}$
}

\begin{abstract}
This investigation aims to discuss the methodologies applied in clinical trials published about Carisolv $^{\mathrm{TM}}$, in order to assess the best scientific evidence concerning chemo-mechanical caries removal. Papers concerning the use of Carisolv ${ }^{\mathrm{TM}}$ were sought using a search strategy. The titles and abstracts of all the reports identified through the search were analyzed by a single reviewer. The inclusion criterion involved: clinical trials having Carisolv $^{\mathrm{TM}}$ in one of the study groups. Then, those that fulfilled the inclusion criterion underwent methodology assessment and data extraction. Only 12 papers met the inclusion criterion. It was observed that none of these studies complied with all the evaluated research methodological principles required in order to have power of evidence generation. Carisolv ${ }^{\mathrm{TM}}$ proved to be effective in caries removal. Appointment mean time was greater, but the perceived time was shorter than that using conventional techniques due to patients' perception of more comfort and a reduction of anesthesia needs. There were no adverse effect in long-term assessments. In studies with microbiological evaluation of the remaining dentine, it was observed that both the conventional and chemo-mechanical methods produced statistically significant reduction on counts of viable microorganisms.
\end{abstract}

DESCRIPTORS: Dental caries/therapy; Effectiveness; Methods.

RESUMO: Esta investigação objetiva discutir as metodologias aplicadas em ensaios clínicos publicados sobre Carisolv $^{\circledR}$, para verificar a melhor evidência científica concernente à remoção químico-mecânica de tecido cariado. Artigos referentes ao uso de Carisolv ${ }^{\circledR}$ foram procurados utilizando-se uma estratégia de busca. Os títulos e resumos de todos os estudos identificados pela procura foram analisados por um único revisor. O critério de inclusão envolveu: ensaios clínicos contendo o sistema Carisolv ${ }^{\circledR}$ em um dos grupos de estudo. Os estudos que preencheram o critério de inclusão foram submetidos à avaliação de metodologia e extração de dados. Somente 12 artigos preencheram o critério para inclusão. Foi verificado que nenhum desses estudos obedeceu a todos os princípios metodológicos considerados necessários para que uma pesquisa tenha poder de geração de evidências. O Carisolv ${ }^{\circledast}$ demonstrou ser eficaz na remoção de tecido cariado. O tempo de consulta foi maior, mas o tempo percebido foi inferior em comparação ao tempo das técnicas convencionais devido à percepção dos pacientes de mais conforto e de redução da necessidade de anestesia. Não houve efeito adverso em avaliações a longo prazo. Em estudos com avaliação microbiológica da dentina remanescente foi verificado que ambos os métodos convencional e químico-mecânico produziram redução significativa na contagem de microrganismos viáveis.

DESCRITORES: Cárie dentária/terapia; Efetividade; Métodos.

\section{INTRODUCTION}

Evidence-based medicine is the conscious, clear and cautious use of the current best evidence to make decisions when treating individual patients. ${ }^{25}$ Nowadays systematic reviews are considered the preferred method for identifying all of the available knowledge, determining which information is the best and summarizing it in a clinically useful manner. ${ }^{2}$

Despite the caries prevalence decline ${ }^{7}$, carious tissue removal, still a challenge for researchers, is

* MS, Graduate Student, Pediatric Dentistry, School of Dentistry, University of São Paulo.

** PhDs, Associate Professors; ***MS, Associate Professor; ${ }^{* * *} \mathrm{MS}-$ Pediatric Dentistry, Lutheran University of Brazil. 
Marquezan M, Faraco Junior IM, Feldens CA, Tovo MF, Ottoni AB. Evaluation of the methodologies used in clinical trials and effectiveness of chemo-mechanical caries removal with Carisolv ${ }^{\mathrm{TM}}$. Braz Oral Res 2006;20(4):364-71.

considered an unpleasant step of the restorative process, mainly because of the need for local anesthesia, drilling and noise. , $^{15,6,9,12,15,18}$ Furthermore, drilling results in a rapid and excessive removal of affected dentin ${ }^{10}$ and may cause harmful thermal and pressure effects to the pulp. . $^{15,12,15,18}$ The advances in adhesive dentistry have changed the need for standard cavity designs allowing minimally invasive techniques. ${ }^{6,14,17,18}$ The chemo-mechanical caries removal system Carisolv ${ }^{\mathrm{TM}}$ has been developed with the purpose of removing all the infected tissue, preventing the removal of sound dentin, and is intended not to cause discomfort to the patient. 6,9 The system is a gel constituted of $0.5 \%$ sodium hypochlorite and three amino acids, glutamic acid, leucin and lysine. Sodium hypochlorite has a non-specific proteolytic effect which dissolves organic substances as a result of the action of chlorine, which breaks collagen net links. Thanks to the amino acids present in Carisolv $^{\mathrm{TM}}$, there is a reduction of this effect, allowing selective caries removal by differentiating sound, bacteria-free tissue from the infected, disnatured and irretrievable dentin. ${ }^{9}$

Because of the variety of papers involving $\mathrm{Ca}-$ risolv ${ }^{\mathrm{TM}}$, the present investigation aimed to discuss the methodologies applied in the clinical trials published about this system in order to assess the best scientific evidence concerning the efficacy and safety of chemo-mechanical caries removal. The key question stated was: "Is Carisolv" ${ }^{\mathrm{TM}}$ effective in caries removal? And is it more comfortable compared to conventional methods?"

\section{MATERIAL AND METHODS}

This methodology followed the format of a systematic review. ${ }^{4}$

\section{Search strategy for identification of studies}

Papers concerning the use of the chemo-mechanical caries removal system Carisolv ${ }^{\mathrm{TM}}$ (Medi Team, Gothenburg, Sweden) published until May 2005 were searched. The following databases were examined: PubMed, Cochrane Library and Bireme. The descriptors typed were: Carisolv or chemomechanical and caries and removal. The idioms were restricted to Portuguese and English. Titles and abstracts of all reports identified through the searches were analyzed by a single reviewer. The inclusion criterion involved: Clinical trials having Carisolv $^{\mathrm{TM}}$ in one of the study groups. Studies that fulfilled the inclusion criterion underwent meth- odology assessment and data extraction by full text analysis. ${ }^{4}$ Selected papers references were also examined. No attempt to identify grey literature or unpublished data was done.

\section{Studies analysis}

The same reviewer assessed each complete study regarding methodological aspects in order to assess its power of evidence generation. The following principles were considered in the assessment: sample size, well defined inclusion and exclusion criteria, randomization, control group, calibration, examiner blinding, statistical analysis and long-term follow-up. Data extraction comprised the studies' main characteristics and analysis of the results and its arrangement in tables.

\section{RESULTS}

Only 12 papers fulfilled the inclusion criterion: clinical trial having Carisolv ${ }^{\mathrm{TM}}$ in one of the study groups. One clinical trial primarily selected was excluded during methodology assessment because Carisolv $^{\mathrm{TM}}$ had been used associated with air-abrasion. ${ }^{24}$

Table 1 presents the 12 selected studies, their respective authors, and methodology features. Table 2 presents the 12 selected studies, their respective authors, and their main features. Table 3 presents the 12 selected studies, their respective authors, and their main results.

\section{DISCUSSION}

A clinical trial is a planned experiment, strictly on human subjects, which is conducted with a view to investigate the efficacy of one or more treatments for a given condition. ${ }^{22}$ This kind of research offers us the most trustworthy evidence. All selected papers in this review are clinical trials. In vitro studies can serve as hypothesis generators and indicators of possible correlations but have the uncertainty of extrapolating results to physiological effects in humans, thus presenting weak evidence. ${ }^{16}$ For that reason they have been excluded in this review.

Investigators are interested in the effect of some "intervention" or "treatment" in a particular target population. It is possible to use statistical techniques to make inferences about the population of patients who will present to a practitioner in the future by using information obtained from a sample of patients in a trial. ${ }^{22}$ Considering infer- 
Marquezan M, Faraco Junior IM, Feldens CA, Tovo MF, Ottoni AB. Evaluation of the methodologies used in clinical trials and effectiveness of chemo-mechanical caries removal with Carisolv ${ }^{\mathrm{TM}}$. Braz Oral Res 2006;20(4):364-71.

TABLE 1 - Methodology assessment.

\begin{tabular}{|c|c|c|c|c|c|c|c|c|c|}
\hline 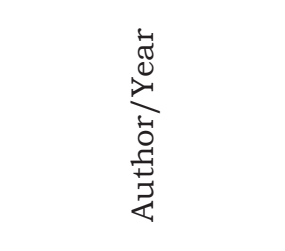 & 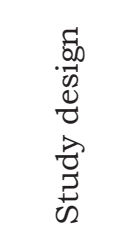 & 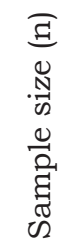 & 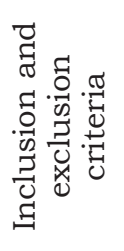 & 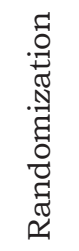 & 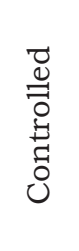 & 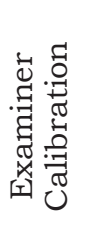 & 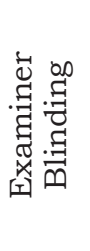 & 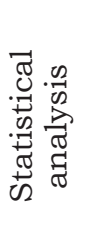 & 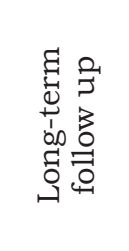 \\
\hline $\begin{array}{l}\text { Ericson et al. }{ }^{6} \\
(1999)\end{array}$ & Parallel & 127 & Yes & Yes & Yes & - & Yes & Yes & $\begin{array}{c}6 \\
\text { months }\end{array}$ \\
\hline $\begin{array}{l}\text { Fure et al. }{ }^{9} \\
(2000)\end{array}$ & Parallel & 60 & Yes & Yes & Yes & - & Yes & Yes & $\begin{array}{c}12 \\
\text { months }\end{array}$ \\
\hline $\begin{array}{l}\text { Maragakis et al. }{ }^{15} \\
(2001)\end{array}$ & $\begin{array}{l}\text { Split } \\
\text { mouth }\end{array}$ & 32 & Yes & Yes & Yes & - & - & Yes & 1 week \\
\hline $\begin{array}{l}\text { Munshi et al. }{ }^{17} \\
(2001)\end{array}$ & Parallel & 50 & Yes & - & - & - & - & Yes & $\begin{array}{c}6 \\
\text { months }\end{array}$ \\
\hline $\begin{array}{l}\text { Nadanovsky et } \\
\text { al. }^{18}(2001)^{*}\end{array}$ & $\begin{array}{l}\text { Split } \\
\text { mouth }\end{array}$ & 132 & Yes & Yes & Yes & Yes & Yes & Yes & - \\
\hline $\begin{array}{l}\text { Chaussain-Miller } \\
\text { et al. }{ }^{5}(2003)\end{array}$ & Parallel & 120 & Yes & Yes & - & - & - & Yes & - \\
\hline $\begin{array}{l}\text { Kakaboura et } \\
\text { al. }{ }^{12}(2003)\end{array}$ & $\begin{array}{l}\text { Split } \\
\text { mouth }\end{array}$ & 90 & Yes & Yes & Yes & - & Yes & Yes & - \\
\hline $\begin{array}{l}\text { Lager et al. }{ }^{14} \\
(2003)\end{array}$ & Parallel & 22 & Yes & Yes & Yes & - & - & Yes & - \\
\hline $\begin{array}{l}\text { Fure, Lingström } \\
(2004)\end{array}$ & Parallel & 202 & Yes & Yes & - & - & Yes & Yes & $\begin{array}{c}12 \\
\text { months }\end{array}$ \\
\hline $\begin{array}{l}\text { Kavvadia et } \text { al. }^{13} \\
(2004)\end{array}$ & Parallel & 92 & Yes & Yes & Yes & Yes & - & Yes & \\
\hline $\begin{array}{l}\text { Azrak et al. }{ }^{1} \\
(2004)\end{array}$ & $\begin{array}{l}\text { Split } \\
\text { mouth }\end{array}$ & 42 & Yes & Yes & Yes & - & - & Yes & - \\
\hline $\begin{array}{l}\text { Bergmann et al. }{ }^{3} \\
(2005)\end{array}$ & $\begin{array}{l}\text { Split } \\
\text { mouth }\end{array}$ & 46 & Yes & Yes & Yes & - & Yes & Yes & $\begin{array}{c}6 \\
\text { months }\end{array}$ \\
\hline
\end{tabular}

*Sample size estimation.

ence ability, all the assessed studies in this review carried out adequate statistical analysis.

Selection bias occurs when the individuals in the study are not representative of the population of interest. This may be avoided by ensuring that a random method of selection is used rather than relying on purposive or judgment sampling, where investigators include in their samples those individuals who they believe are typical or representative of the population. ${ }^{20}$ In this review it was observed that all the clinical trials evaluated used a convenience sample. This could have an implication on the results since people that have access to dental treatment may differ from the target population in terms of caries activity and psychological profile.

The aim in designing a study is to control $\alpha$ and $\beta$. Since they both increase as the sample size of the study decreases, all other relevant factors remain- ing constant, estimating sample size becomes an integral part of study design. ${ }^{23}$ From the analyzed studies, only Nadanovsky et al. ${ }^{18}$ (2001) mentioned to have calculated the necessary sample size.

Clinicians may have a preconceived notion related to the effectiveness of a new treatment and this will influence the way in which the patients are allocated to various treatments. This might result in the more severely ill patients being allocated to the standard treatment, or vice-versa, even if the clinician's intention is to be fair, and this in turn would result in a biased estimate of the treatment effect. In order to avoid the possibility of this happening, the patients are randomly assigned treatments. ${ }^{22}$ If the size of the sample is enough, randomization guarantees that some results determinants known and unknown by the researcher are randomly distributed between test and control groups. Not randomized trials of ef- 
Marquezan M, Faraco Junior IM, Feldens CA, Tovo MF, Ottoni AB. Evaluation of the methodologies used in clinical trials and effectiveness of chemo-mechanical caries removal with Carisolv ${ }^{\mathrm{TM}}$. Braz Oral Res 2006;20(4):364-71.

TABLE 2 - Data extraction: Studies Features.

\begin{tabular}{|c|c|c|c|c|}
\hline Author/Year & Country & Population/Age & Lesions caracteristics & $\begin{array}{c}\text { Caries } \\
\text { diagnosis }\end{array}$ \\
\hline $\begin{array}{l}\text { Ericson et } \\
\text { al. }^{6}(1999)\end{array}$ & Sweden & $\begin{array}{l}\text { - } 127 \text { patients of various } \\
\text { profiles } \\
\text { - age } 3-85 y\end{array}$ & $\begin{array}{l}\text { - Active primary caries lesion with } \\
\text { dentine involvement in tooth with } \\
\text { positive sensitivity response }\end{array}$ & $\begin{array}{l}\text { Clinical and } \\
\text { radiographic }\end{array}$ \\
\hline $\begin{array}{l}\text { Fure et al. }{ }^{9} \\
(2000)\end{array}$ & Sweden & $\begin{array}{l}\text { - } 38 \text { adults } \\
\text { - age } 23-84 \text { y }\end{array}$ & $\begin{array}{l}\text { - Active primary root carious lesion } \\
\text { with softened dentine in a vital tooth } \\
\text { - } 2 \mathrm{~mm}\end{array}$ & Clinical \\
\hline $\begin{array}{l}\text { Maragakis et } \\
\text { al. }^{15}(2001)\end{array}$ & Greece & $\begin{array}{l}\text { - } 16 \text { children } \\
\text { - age } 7 \text { - } 9\end{array}$ & $\begin{array}{l}\text { - Contralateral occlusal primary } \\
\text { decay with open access in vital } \\
\text { molars } \\
\text { - } \varnothing 1.5 \mathrm{~mm}\end{array}$ & Clinical \\
\hline $\begin{array}{l}\text { Munshi et } \\
\text { al. }^{17}(2001)\end{array}$ & India & $\begin{array}{l}\text { - } 50 \text { children } \\
\text { - age } 3 \text { - } 12 \text { y }\end{array}$ & $\begin{array}{l}\text { - Dentinal lesion in primary and } \\
\text { permanent molars }\end{array}$ & $\begin{array}{l}\text { Clinical and } \\
\text { radiographic }\end{array}$ \\
\hline $\begin{array}{l}\text { Nadanovsky } \\
\text { et al. }{ }^{18}(2001)\end{array}$ & Brazil & $\begin{array}{l}\text { - } 66 \text { people from poor } \\
\text { community } \\
\text { - age } 6-44 \mathrm{y}\end{array}$ & $\begin{array}{l}\text { - Primary caries cavity in dentin in } \\
\text { permanent teeth, sound pulp }\end{array}$ & Clinical \\
\hline $\begin{array}{l}\text { Chaussain- } \\
\text { Miller et al. }{ }^{5} \\
(2003)\end{array}$ & France & $\begin{array}{l}\text { - } 96 \text { volunteer patients } \\
\text { - age } 10-81 \mathrm{y}\end{array}$ & $\begin{array}{l}\text { - Active carious lesion with dentin } \\
\text { involvement on a vital tooth }\end{array}$ & $\begin{array}{l}\text { Clinical and } \\
\text { radiographic }\end{array}$ \\
\hline $\begin{array}{l}\text { Kakaboura et } \\
\text { al. }^{12} \text { (2003) }\end{array}$ & Greece & $\begin{array}{l}\text { - } 45 \text { volunteer patients } \\
\text { - age } 18-55 \text { y }\end{array}$ & $\begin{array}{l}\text { - Primary coronal mesio-occlusal or } \\
\text { disto-occlusal carious lesions }\end{array}$ & Clinical \\
\hline $\begin{array}{l}\text { Lager et al. }{ }^{14} \\
(2003)\end{array}$ & Sweden & $\begin{array}{l}\text { - } 22 \text { Consecutive adult } \\
\text { patients from Dentistry } \\
\text { School } \\
\text { - age } 20-68 \text { y }\end{array}$ & $\begin{array}{l}\text { - Vital premolars with primary caries } \\
\text { involving half dentin thickness } \\
\text { or primary buccal caries lesions } \\
\text { extending into dentin. Consistency } \\
\text { medium hard and color yellow to } \\
\text { light brown }\end{array}$ & $\begin{array}{l}\text { Clinical and } \\
\text { radiographic }\end{array}$ \\
\hline $\begin{array}{l}\text { Fure, } \\
\text { Lingström } \\
(2004)\end{array}$ & Sweden & $\begin{array}{l}\text { - } 170 \text { Consecutive adult } \\
\text { patients from dental } \\
\text { clinics } \\
\text { - age } 19-85 \mathrm{y}\end{array}$ & - Carious dentin lesions & $\begin{array}{l}\text { Clinical and } \\
\text { radiographic }\end{array}$ \\
\hline $\begin{array}{l}\text { Kavvadia et } \\
\text { al. }^{13}(2004)\end{array}$ & Greece & $\begin{array}{l}\text { - } 31 \text { Patients of the } \\
\text { Pediatric Dentistry } \\
\text { Department at Athens' } \\
\text { University } \\
\text { - age } 28 \mathrm{~m}-9 \mathrm{y}\end{array}$ & $\begin{array}{l}\text { - Open carious lesion into dentin, on } \\
\text { occlusal or buccal anterior surfaces }\end{array}$ & $\begin{array}{l}\text { Clinical and } \\
\text { radiographic }\end{array}$ \\
\hline $\begin{array}{l}\text { Azrak et al. }{ }^{1} \\
(2004)\end{array}$ & Germany & $\begin{array}{l}\text { - } 21 \text { Children with early } \\
\text { childhood caries treated } \\
\text { under local anesthesia } \\
\text { - age } 24-70 \mathrm{~m}\end{array}$ & $\begin{array}{l}\text { - Primary molars with brown and } \\
\text { softened dentine }\end{array}$ & Clinical \\
\hline $\begin{array}{l}\text { Bergmann et } \\
\text { al. }^{3}(2005)\end{array}$ & $\begin{array}{l}\text { Denmark/ } \\
\text { Portugal }\end{array}$ & $\begin{array}{l}\text { - } 46 \text { Consecutive pediatric } \\
\text { patients } \\
\text { - } 4-11 \mathrm{y} \\
\end{array}$ & $\begin{array}{l}\text { - Active dentine carious lesions in } \\
\text { deciduous teeth }\end{array}$ & Clinical \\
\hline
\end{tabular}

fectiveness are inevitably limited in its ability of distinction between useful and useless or even harmful therapies. ${ }^{11}$ The great majority of the investigated studies distributed patients or teeth into test or control groups by chance, except that of Munshi et al. ${ }^{17}$ (2001).

A group which does not receive the test therapy is the reference to assess superiority or equivalence. ${ }^{22}$ Clinical trials in dentistry normally use two types of study design: parallel and split mouth. The parallel group design relies on comparisons which are made between groups of subjects. Split-mouth has the advantage of avoiding variation among individuals, because it uses individuals as their own controls, but cannot be utilized for conditions which do not remain stable in the study period or which can be cured by the treatments being administered, when there is a carry-over effect from 
Marquezan M, Faraco Junior IM, Feldens CA, Tovo MF, Ottoni AB. Evaluation of the methodologies used in clinical trials and effectiveness of chemo-mechanical caries removal with Carisolv ${ }^{\mathrm{TM}}$. Braz Oral Res 2006;20(4):364-71.

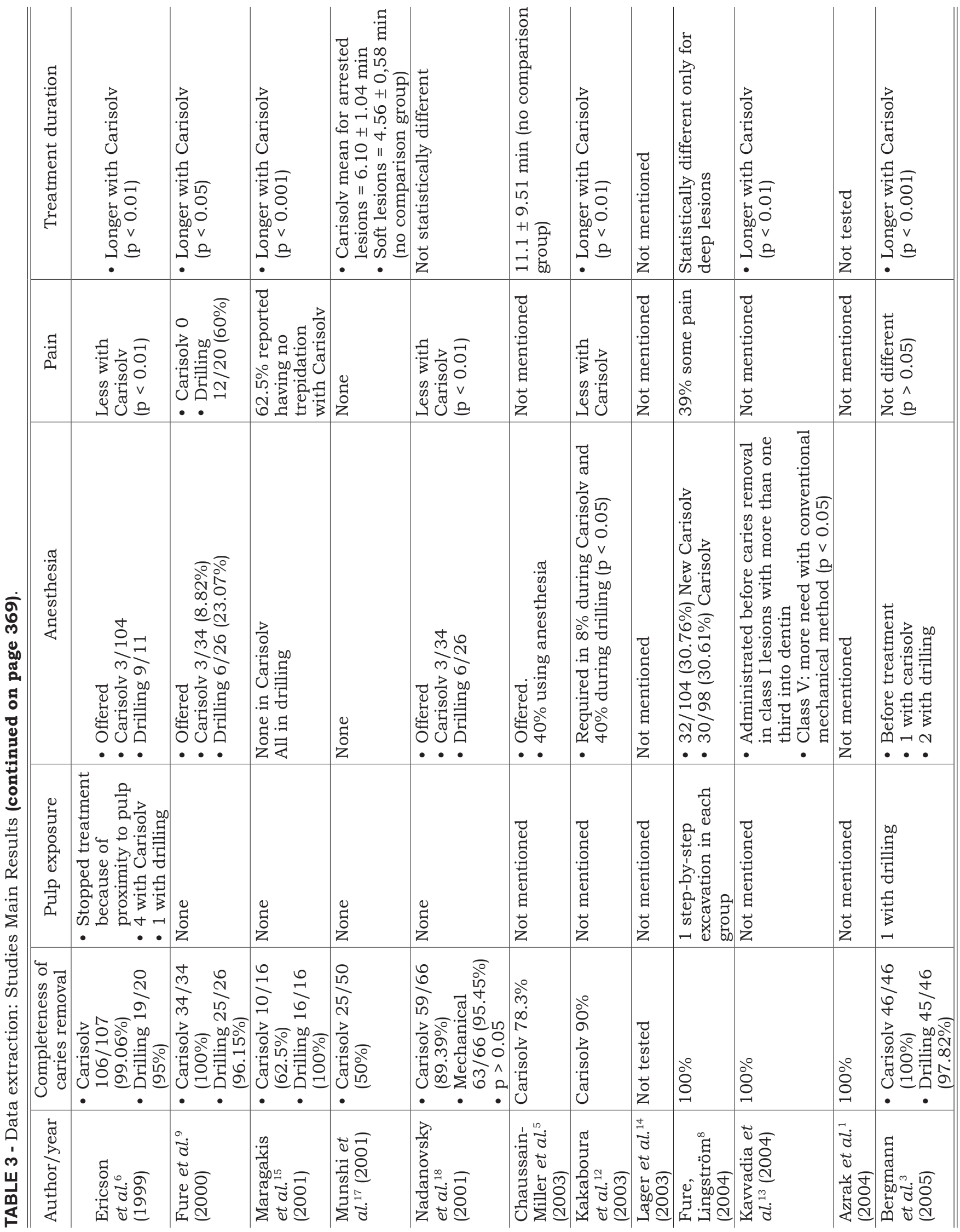




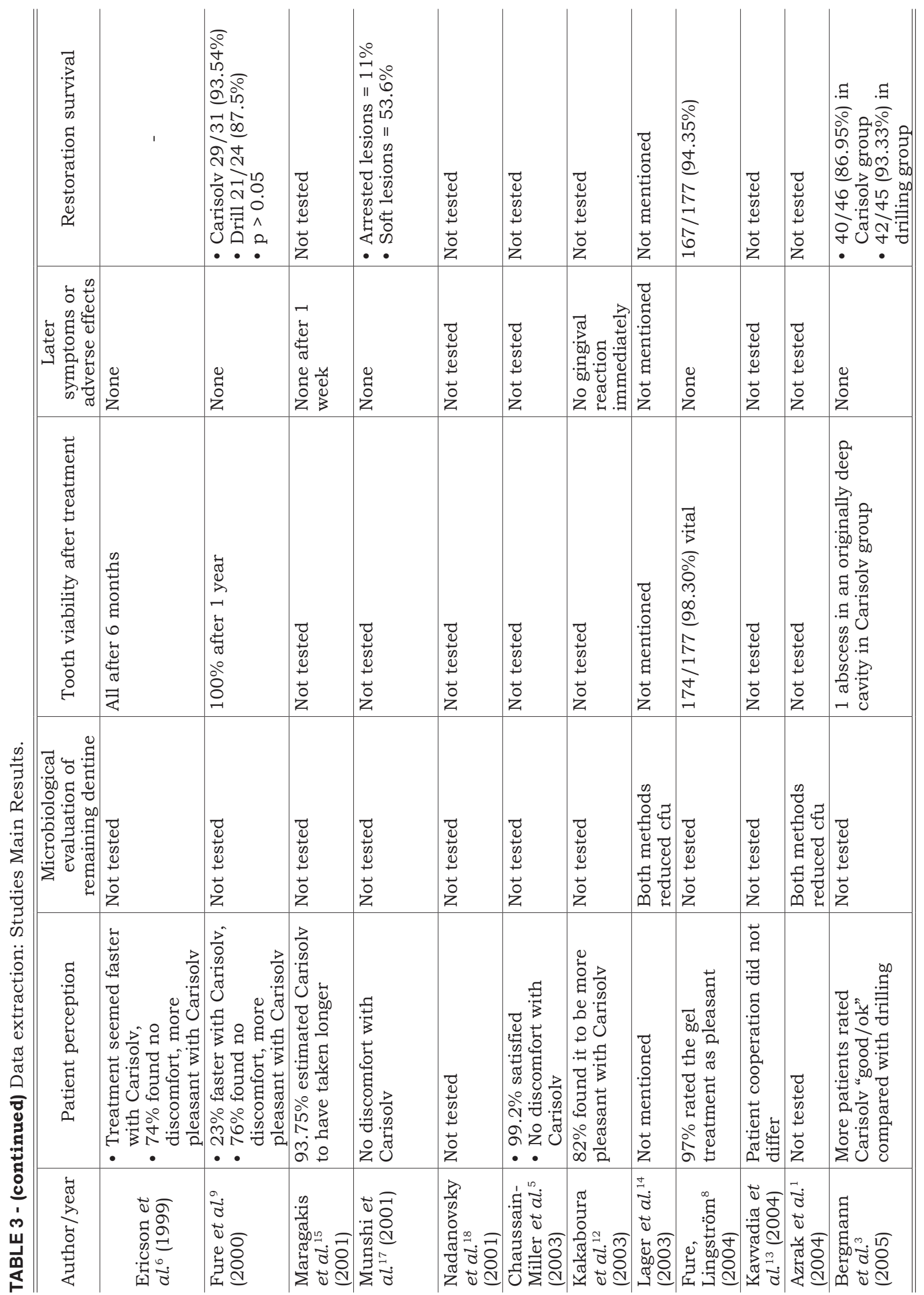


Marquezan M, Faraco Junior IM, Feldens CA, Tovo MF, Ottoni AB. Evaluation of the methodologies used in clinical trials and effectiveness of chemo-mechanical caries removal with Carisolv ${ }^{\mathrm{TM}}$. Braz Oral Res 2006;20(4):364-71.

one treatment to another, or when the response to treatment is prolonged. ${ }^{21}$ From the 12 analyzed papers, nine $e^{3,6,9,13,15,18}$ used the conventional technique of caries removal by burs and or hand instruments as control group for Carisolv ${ }^{\mathrm{TM}}$. Concerning study design, the great majority of studies used a parallel model $^{5,6,8,9,13,14,17}$ while others ${ }^{1,3,12,15,18}$ used a split mouth model.

Calibration aims to guarantee the uniformity of interpretation and application of adopted criteria by examiners both in relation to themselves and to the other examiners. ${ }^{26}$ Ideally, reproducibility should be calculated by Cohen's Kappa coefficient, in order to deduct agreements by chance. ${ }^{19}$ Interexaminers calibration was demonstrated by Kavvadia et al. ${ }^{13}$ (2004) and Nadanovsky et al. ${ }^{18}$ (2001).

Both the patient receiving treatment and the assessor of the response to treatment may have preconceived notions about the superiority of one treatment over another. If either is aware of which treatment the patient is receiving, this may influence the assessor's evaluation of the response and lead to a biased result. ${ }^{22}$ In trials where patient and operator can not be blinded, the examiner who assesses the results must be. ${ }^{11}$ Bergmann et $a .^{3}{ }^{3}$ (2005), Ericson et al. ${ }^{6}$ (1999), Fure et al. ${ }^{9}$ (2000), Fure, Lingström ${ }^{8}$ (2004), Kakaboura et al. ${ }^{12}$ (2003) and Nadanovsky et al. ${ }^{18}$ (2001) all mentioned examiner's blinding.

A long-term follow-up is essential to evaluate a drug or technique safety. Longitudinal studies are the best ones regarding ability of evaluating later symptoms or adverse effects, although they present a high cost and a great possibility of individual drop outs. ${ }^{21}$ Maragakis et al. ${ }^{15}$ (2001) evaluated 16 children after one week. Ericson et al. ${ }^{6}$ (1999), Munshi et al. ${ }^{17}$ (2001), Fure et al. ${ }^{9}$ (2000), Fure, Lingström $^{8}(2004)$ and Bergmann et al. ${ }^{3}(2005)$ recalled patients after six months or one year. All longitudinal studies found no later symptoms or adverse

\section{REFERENCES}

1. Azrak B, Callaway A, Grundheber A, Stender E, Willershausen B. Comparison of the efficacy of chemomechanical caries removal (Carisolv ${ }^{\mathrm{TM}}$ ) with that of conventional excavation in reducing the cariogenic flora. Int $\mathrm{J}$ Paediatr Dent. 2004;14:182-91.

2. Bader J, Ismail A. Survey of systematic reviews in dentistry. J Am Dent Assoc. 2004;135(4):464-73.

3. Bergmann J, Leitão J, Kultje C, Bergmann D, Clode MJ. Removing dentine caries in deciduous teeth with Carisolv: a randomised, controlled, prospective study with six-month follow-up, comparing chemomechanical treatment with drilling. Oral Health Prev Dent. 2005;3(2):105-11. effects. Fure et al. ${ }^{9}$ (2000), Fure, Lingström ${ }^{8}$ (2004) and Bergmann et al. ${ }^{3}$ (2005) assessed restoration quality during follow-up and found a satisfactory success rate.

Cavities restorative treatment is a wide issue in cariology, and there is no particular technique which is useful in all situations. Intrinsic differences of each patient, including cooperation level, oral health appraisal and general health conditions make the consensus about a therapy more difficult. Based on the available clinical trials results, Carisolv $^{\mathrm{TM}}$ demonstrated to be effective in caries removal. ${ }^{1,3,6,9,12,13,18}$ Appointment mean time was great$\mathrm{er}^{3,6,8,9,12,13,15}$ but due to patient perception of more comfort $^{3,5,8,9,12,17}$ and reduced anesthesia necessity $6,9,12,13,15,18$, the perceived time was shorter than that observed using conventional techniques. ${ }^{6,9}$ The system was considered adequate for pediatric use because it did not affect child cooperation ${ }^{13,17}$. However, in the study by Maragakis et al. ${ }^{15}$ (2001), the majority of pediatric patients preferred the conventional technique because it was faster and did not produce an unpleasant flavor. There were no adverse effects in long-term assessments. ${ }^{3,6,8,9,15,17}$ In studies involving a microbiological evaluation of the remaining dentine, it was observed that both the conventional and the chemo-mechanical methods produced a statistical significant reduction on counts of viable microorganisms. ${ }^{1,14}$

\section{CONCLUSIONS}

Based on the available clinical trials related to Carisolv ${ }^{\mathrm{TM}}$, it was observed that none of the studies complied with all research methodological principles. However, the best available evidence concerning Carisolv ${ }^{\mathrm{TM}}$ suggests that it is effective in caries removal and ensures higher patient comfort than does conventional drilling, although it involves a longer appointment.
4. Braun A, Eberhard J, Krause F, Glenny AM, Jepsen S. Chemo-mechanical treatment of tooth decay [protocol]. The Cochrane Library, Issue, 2006. Oxford: Update Software.

5. Chaussain-Miller C, Decup F, Domejean-Orliaguet S, Gillet D, Guigand M, Kaleka R et al. Clinical evaluation of the Carisolv chemomechanical caries removal technique according to the site/stage concept, a revised caries classification system. Clin Oral Investig. 2003;7(1):32-7.

6. Ericson D, Zimmerman M, Raber H, Gotrick B, Bornstein $\mathrm{R}$, Thorell J. Clinical evaluation of efficacy and safety of a new method for chemo-mechanical removal of caries. A multi-centre study. Caries Res. 1999;33(3):171-7. 
Marquezan M, Faraco Junior IM, Feldens CA, Tovo MF, Ottoni AB. Evaluation of the methodologies used in clinical trials and effectiveness of chemo-mechanical caries removal with Carisolv ${ }^{\mathrm{TM}}$. Braz Oral Res 2006;20(4):364-71.

7. Fejerskov O. Concepts of dental caries and their consequences for understanding the disease. Community Dent Oral Epidemiol. 1997;25(1):5-12.

8. Fure S, Lingstrom P. Evaluation of the chemomechanical removal of dentine caries in vivo with a new modified Carisolv gel. Clin Oral Investig. 2004;8(3):139-44.

9. Fure S, Lingstrom P, Birkhed D. Evaluation of Carisolv for the chemo-mechanical removal of primary root caries in vivo. Caries Res. 2000;34(3):275-80.

10. Fusayama T. Clinical guide for removing caries using a caries-detecting solution. Quintessence Int. 1988;19(6):397401.

11. Guyatt GH, Sackett DL, Cook DJ. Users' guides to the medical literature. II. How to use an article about therapy or prevention. A. Are the results of the study valid? EvidenceBased Medicine Working Group. JAMA. 1993;270(21):2598601.

12. Kakaboura A, Masouras C, Staikou O, Vougiouklakis G. A comparative clinical study on the Carisolv caries removal method. Quintessence Int. 2003;34(4):269-71.

13. Kavvadia K, Karagianni V, Polychronopoulou A, Papagiannouli L. Primary teeth caries removal using the Carisolv chemomechanical method: a clinical trial. Pediatr Dent. 2004;26(1):23-8.

14. Lager A, Thornqvist E, Ericson D. Cultivatable bacteria in dentine after caries excavation using rose-bur or Carisolv $^{\mathrm{TM}}$. Caries Res. 2003;37(3):206-11.

15. Maragakis GM, Hahn P, Hellwig E. Clinical evaluation of chemomechanical caries removal in primary molars and its acceptance by patients. Caries Res. 2001;35(3):20510 .

16. Mickenautsch S, Yengopal V, Bonecker M, Leal SC, Bezerra ACB, Oliveira LB. Minimum Intervention (MI) Dentistry - Evidence based Compendium. $1^{\text {st }}$ Edition. MI Corpo- ration; 2006. Disponivel em: URL: http://www.midentistry. com [accessed on 2006 Mar 21].

17. Munshi AK, Hegde AM, Shetty PK. Clinical evaluation of Carisolv in the chemico-mechanical removal of carious dentin. J Clin Pediatr Dent. 2001;26(1):49-54.

18. Nadanovsky P, Cohen Carneiro F, Souza de Mello F. Removal of caries using only hand instruments: a comparison of mechanical and chemo-mechanical methods. Caries Res. 2001;35(5):384-9.

19. Peres MA, Traebert J, Macenes W. Calibração de examinadores para estudos epidemiológicos de cárie dentária. Cad Saúde Pública. 2001;17(1):153-9.

20. Petrie A, Bulman JS, Osborn JF. Further statistics in dentistry. Part 1: Research designs 1. Br Dent J. 2002; 193(7):377-80.

21. Petrie A, Bulman JS, Osborn JF. Further statistics in dentistry. Part 2: Research designs 2. Br Dent J. 2002; 193(8):435-40.

22. Petrie A, Bulman JS, Osborn JF. Further statistics in dentistry. Part 3: Clinical trials 1. Br Dent J. 2002; 193(9):495-8.

23. Petrie A, Bulman JS, Osborn JF. Further statistics in dentistry. Part 4: Clinical trials 2. Br Dent J. 2002; 193(10):557-61.

24. Rafique S, Fiske J, Banerjee A. Clinical trial of an air-abrasion/chemomechanical operative procedure for the restorative treatment of dental patients. Caries Res. 2003;37(5):360-4.

25. Sackett DL, Rosenberg WM, Gray JA, Haynes RB, Richardson WS. Evidence based medicine: what it is and what it isn't. Br Med J. 1996;312(7023):71-2.

26. WHO (World Health Organization). Calibration of Examiners for Oral Health Epidemiology Surveys - Technical Report. Geneva: WHO; 1993. 